\title{
Value Evaluation of Inclusive Innovation System Empirical Study on Rural E-commerce in China
}

\author{
Kun Wang ${ }^{1,}$, Yuqing Han ${ }^{2}$ \\ ${ }^{1,2}$ School of Business, Tianjin University of Finance and Economics, Tianjin 300222, China; \\ a haoyuan1314age@163.com
}

Keyword: inclusive innovation, innovation system, value evaluation.

\begin{abstract}
By constructing the hierarchical regression model, it is verified that the inclusive innovation system has a positive effect on solving the problems of rural poverty, peasants employment, gender inequality and changing people's ideas, to further validate China inclusive innovation form of rural e-commerce to promote inclusive development of China's economy and society. Through the evaluation of the value of the inclusive innovation system, it is found that the emergence of rural e-commerce in China has solved the problem of poverty in rural areas, promoted the employment of the labor force, improved the gender inequality and changed the peasants' thinking concept, and provided a new way to evaluate the social value of inclusive innovation system.
\end{abstract}

\section{Introduction}

Through the study of inclusive innovation operation mechanism and value evaluation, the research aims to provide theoretical support and policy suggestions to improve the healthy operation of Taobao Village, enhance the innovation performance of rural electricity suppliers, promote the development of rural economy, and improve the living standard of peasants. To provide accurate theoretical basis for poverty alleviation, poverty alleviation and green poverty reduction.

\section{Literature References}

George argues that inclusive innovation can be seen as an innovation that promotes inclusive growth, namely the development and implementation of new ideas that create opportunities for excluded BOP groups in existing socio-economic systems to enhance their economic and social well-being (George G, McGahan AM, Prabhu J, 2012). Prahalad and Hart proposed the strategy of Base of the Pyramid (BOP). Inclusive innovation mainly refers to the bottom groups of pyramids, who live under the poverty line and whose rights are not fully guaranteed. This group contains huge Business opportunities. Enterprises can satisfy their inherent needs or utilize their innovative capabilities through business model innovation and technological innovation. They not only can obtain huge economic returns, but also improve the quality of life of low-income groups to alleviate and eliminate poverty.

\section{Model framework and Empirical Research}

3.1 This section takes rural e-commerce as a measure of poverty eradication as a measure of income disparity before and after opening a shop and verifies the impact of inclusive innovation on poverty alleviation through the impact of inclusive innovation performance on income disparity. Inclusive innovation performance as an indicator of inclusive innovation system, this chapter continues to use inclusive innovation performance to characterize the effect of inclusive innovation system change, but the inclusive innovation performance as an explanatory variable to test the inclusive innovation system Implications for improving poverty and addressing other research issues in this chapter.

H1: The higher the degree of inclusive innovation, the greater the income gap, which the better 
the solution to poverty.

$$
\text { Gap_income }_{i}=\alpha_{i}+\beta_{1} \text { per }_{i}+\beta_{2} \text { new }_{i}+\beta_{3} \text { tra }_{i}+\beta_{4} \text { fre } e_{i}+\gamma_{1} \text { for_emp }+\gamma_{2} \text { Gdi_num }_{i}+\gamma_{3} \text { lea }_{i}+\varepsilon_{i}
$$

Table 1 Regression analysis results

\begin{tabular}{|c|c|c|c|c|c|c|}
\hline variable & (1) & (2) & (3) & (4) & (5) & (6) \\
\hline per & $\begin{array}{l}0.094^{* * *} \\
(0.706)\end{array}$ & & & & $\begin{array}{c}0.516^{* * *} \\
(0.325) \\
\end{array}$ & $\begin{array}{l}0.014 * * * \\
(0.717) \\
\end{array}$ \\
\hline new & & $\begin{array}{c}0.184 * \\
(0.694) \\
\end{array}$ & & & $\begin{array}{c}0.055^{* *} \\
(95.244) \\
\end{array}$ & $\begin{array}{l}0.672 * \\
(0.491) \\
\end{array}$ \\
\hline tra & & & $\begin{array}{c}0.853^{* *} \\
(0.960) \\
\end{array}$ & & $\begin{array}{c}0.532 * * * \\
(0.146) \\
\end{array}$ & $\begin{array}{l}0.845^{* *} \\
(0.521) \\
\end{array}$ \\
\hline fre & & & & $\begin{array}{c}-0.474^{*} \\
(24.168)\end{array}$ & $\begin{array}{l}-0.490 * \\
(0.366)\end{array}$ & $\begin{array}{c}-0.022^{*} \\
(0.953)\end{array}$ \\
\hline for_emp & $\begin{array}{c}0.192 \\
(0.470)\end{array}$ & $\begin{array}{l}-0.306 \\
(0.482)\end{array}$ & $\begin{array}{r}0.265 \\
(0.176)\end{array}$ & $\begin{array}{c}-0.477 \\
(0.166)\end{array}$ & $\begin{array}{c}-0.288 \\
(0.903)\end{array}$ & \\
\hline Gdi_num & $\begin{array}{l}0.605^{* * *} \\
(0.815)\end{array}$ & $\begin{array}{c}0.794 * * * \\
(0.652)\end{array}$ & $\begin{array}{c}0.175 * * \\
(0.559) \\
\end{array}$ & $\begin{array}{l}0.784^{* * *} \\
(0.639)\end{array}$ & $\begin{array}{c}0.315^{* * *} \\
(0.675)\end{array}$ & \\
\hline lea & $\begin{array}{r}0.227 \\
(0.615) \\
\end{array}$ & $\begin{array}{c}0.968 * * \\
(0.194) \\
\end{array}$ & $\begin{array}{c}0.017 * * * \\
(0.570) \\
\end{array}$ & $\begin{array}{l}.453^{* *} \\
(0.745) \\
\end{array}$ & $\begin{array}{c}0.638^{*} \\
(0.996) \\
\end{array}$ & \\
\hline $\mathrm{R} 2$ & 0.669 & 0.385 & 0.394 & 0.376 & 0.693 & 0.149 \\
\hline $\mathrm{N}$ & 367 & 367 & 367 & 367 & 367 & 503 \\
\hline
\end{tabular}

Theorem1. E-business performance, the development of new products, the number of technical training and the degree of informatization have a significant positive impact on poverty eradication.

3.2 This part of the research index chooses to base on the rural women in our country to evaluate the gender inequality from the gender gap indicators such as market participation, economic rights, political rights and educational attainment of rural women. With the development of information technology, the emergence of rural electricity suppliers, low entry conditions, easy interface and government support have given women the opportunity to participate in the market. In addition, they have the opportunity to enhance their ability to question and challenge women. The responsiveness and mobility of their positions and their ability to access information have expanded women's freedoms. Educated women are more likely to enjoy satisfactory jobs and take the initiative. Women can have the opportunity to participate freely in the fair competition in the labor market. They can receive education, open employment, equal pay for work of equal value, and participate in management as men do.

H2: Inclusive innovation has a positive impact on gender equality, inclusiveness that is better innovation performance, the more equality between men and women.

$$
\begin{aligned}
& \text { Gdi_num }{ }_{i}=\alpha_{i}+\beta_{1} \text { per }_{i}+\beta_{2} \text { res }_{-} \text {num }_{i}+\beta_{3} \text { inf }_{i}+\beta_{4} \text { tec } \text { trafee }_{i}+\gamma_{1} g O V_{-} \text {tra }_{i}+\gamma_{2} \text { gov }_{i}+\gamma_{3} d i S_{i}+\gamma_{4} a S S_{i}+\varepsilon_{i}
\end{aligned}
$$

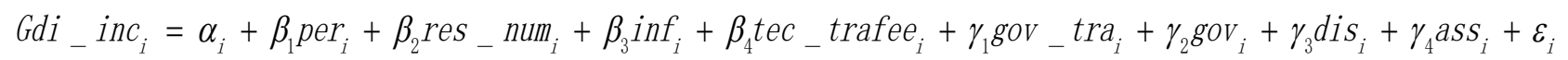

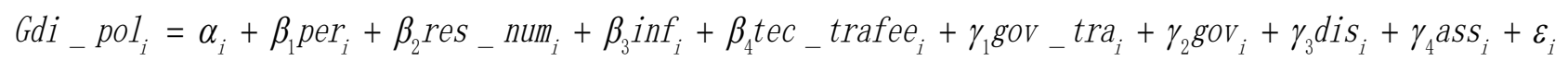


Table 2 Regression analysis results

\begin{tabular}{|c|c|c|c|c|c|c|c|c|c|}
\hline \multirow{3}{*}{$\begin{array}{c}\text { variabl } \\
\mathrm{e}\end{array}$} & \multicolumn{3}{|c|}{ Basic estimation } & \multicolumn{3}{|c|}{ Robustness test } & \multicolumn{3}{|c|}{ Robustness test } \\
\hline & \multicolumn{3}{|c|}{ Gdi_num } & \multicolumn{3}{|c|}{ Gdi_inc } & \multicolumn{3}{|c|}{ Gdi_pol } \\
\hline & $(1)$ & (2) & (3) & (4) & (5) & (6) & (7) & (8) & (9) \\
\hline per & $\begin{array}{c}0.444 * * *(0 . \\
161)\end{array}$ & $\begin{array}{l}0.447 * * * \\
(0.160)\end{array}$ & $\begin{array}{l}0.694 \\
* * * \\
(0.15 \\
2)\end{array}$ & $\begin{array}{c}0.084^{*} \\
* \\
(0.03 \\
0)\end{array}$ & $\begin{array}{c}0.083^{*} \\
* \\
(0.030)\end{array}$ & $\begin{array}{c}0.151 * \\
* * \\
(0.029 \\
)\end{array}$ & $\begin{array}{c}0.198^{*} \\
* * \\
(0.03 \\
1)\end{array}$ & $\begin{array}{c}0.197 * * \\
* \\
(0.031 \\
)\end{array}$ & $\begin{array}{l}0.244 * \\
* * \\
(0.03 \\
0)\end{array}$ \\
\hline $\begin{array}{c}\text { res_nu } \\
m\end{array}$ & $\begin{array}{c}0.478 * * * \\
(0.131)\end{array}$ & $\begin{array}{c}0.466^{*} \\
* * \\
(0.13 \\
1) \\
\end{array}$ & $\begin{array}{c}0.41 \\
1 * * \\
(0.12 \\
3) \\
\end{array}$ & $\begin{array}{c}0.085^{*} \\
* \\
(0.02 \\
6) \\
\end{array}$ & $\begin{array}{c}0.084 * \\
* \\
(0.026)\end{array}$ & $\begin{array}{c}0.061^{*} \\
(0.026 \\
)\end{array}$ & $\begin{array}{c}0.164 * \\
* * \\
(0.02 \\
5)\end{array}$ & $\begin{array}{c}0.162 * * \\
* \\
(0.025 \\
)\end{array}$ & $\begin{array}{l}0.131 * \\
* * \\
(0.02 \\
4)\end{array}$ \\
\hline inf & $\begin{array}{c}-0.891 \\
(1.094)\end{array}$ & $\begin{array}{c}-0.93 \\
5 \\
(1.091 \\
) \\
\end{array}$ & $\begin{array}{c}-0.74 \\
2 \\
(1.06 \\
9) \\
\end{array}$ & $\begin{array}{c}-0.482 * \\
* \\
(0.18 \\
2) \\
\end{array}$ & $\begin{array}{c}-0.484 \\
* * \\
(0.182)\end{array}$ & $\begin{array}{c}-0.602 \\
* * \\
(0.181 \\
)\end{array}$ & $\begin{array}{l}-0.354 \\
(0.21 \\
2)\end{array}$ & $\begin{array}{c}-0.361 \\
(0.21 \\
1)\end{array}$ & $\begin{array}{l}-0.1 \\
08 \\
(0.21 \\
0)\end{array}$ \\
\hline $\begin{array}{c}\text { tec_tra } \\
\text { fee }\end{array}$ & $\begin{array}{c}0.832 * * * \\
(0.166)\end{array}$ & $\begin{array}{c}0.797 * \\
* * \\
(0.167)\end{array}$ & $\begin{array}{c}0.920^{*} \\
* * \\
(0.16 \\
7)\end{array}$ & $\begin{array}{l}0.010 \\
(0.03 \\
4)\end{array}$ & $\begin{array}{c}0.00 \\
8 \\
(0.034)\end{array}$ & $\begin{array}{c}0.026 \\
(0.035 \\
\quad)\end{array}$ & $\begin{array}{c}0.166^{*} \\
* * \\
(0.03 \\
2)\end{array}$ & $\begin{array}{c}0.160 * * \\
* \\
(0.032 \\
)\end{array}$ & $\begin{array}{c}0.197 * \\
* * \\
(0.03 \\
3)\end{array}$ \\
\hline $\begin{array}{c}\text { gov_tr } \\
a\end{array}$ & $\begin{array}{c}-0.956 * \\
(0.402)\end{array}$ & $\begin{array}{c}-0.894^{*} \\
(0.403)\end{array}$ & & $\begin{array}{c}-0.096 \\
(0.075)\end{array}$ & $\begin{array}{c}-0.09 \\
3 \\
(0.075)\end{array}$ & & $\begin{array}{l}-0.051 \\
(0.078)\end{array}$ & $\begin{array}{l}-0.041 \\
(0.078)\end{array}$ & \\
\hline gov & $\begin{array}{l}-0.034^{*} \\
(0.472)\end{array}$ & $\begin{array}{c}-0.182 * \\
(0.478)\end{array}$ & & $\begin{array}{c}-0.314^{*} \\
* * \\
(0.078)\end{array}$ & $\begin{array}{c}-0.319 \\
* * * \\
(0.078)\end{array}$ & & $\begin{array}{c}-0.425 * \\
* * \\
(0.091)\end{array}$ & $\begin{array}{c}-0.449 * \\
* * \\
(0.093)\end{array}$ & \\
\hline dis & $\begin{array}{c}0.562 \\
(0.348)\end{array}$ & $\begin{array}{l}0.500 \\
(0.349)\end{array}$ & & $\begin{array}{c}-0.128^{*} \\
(0.61)\end{array}$ & $\begin{array}{c}-0.131 \\
* \\
(0.061)\end{array}$ & & $\begin{array}{c}0.037 \\
(0.067)\end{array}$ & $\begin{array}{l}0.027 \\
(0.068)\end{array}$ & \\
\hline ass & $\begin{array}{l}-0.834 * \\
(0.930)\end{array}$ & $\begin{array}{l}-0.664 \\
(0.932)\end{array}$ & & $\begin{array}{c}-0.607^{*} \\
* * \\
(0.170)\end{array}$ & $\begin{array}{c}-0.596 \\
* * \\
(0.171)\end{array}$ & & $\begin{array}{l}-0.290 \\
(0.180)\end{array}$ & $\begin{array}{c}-0.263 \\
(0.180\end{array}$ & \\
\hline Edu & $\mathrm{N}$ & $\mathrm{Y}$ & $\mathrm{N}$ & $\mathrm{N}$ & $\mathrm{Y}$ & $\mathrm{N}$ & $\mathrm{N}$ & $\mathrm{Y}$ & $\mathrm{N}$ \\
\hline $\mathrm{R} 2$ & 0.451 & 0.456 & 0.413 & 0.208 & 0.209 & 0.109 & 0.450 & 0.453 & 0.395 \\
\hline $\mathrm{N}$ & 367 & 367 & 367 & 503 & 503 & 503 & 367 & 367 & 367 \\
\hline
\end{tabular}

Theorem2. E-business performance has a significant positive impact on the number of female employees in the online shop, equal pay for equal work, and the number of women in management. The number of $R \& D$ people has a significant positive effect on gender equality. The degree of informatization has a significant positive impact on equal pay for equal work, The cost of technical training has a significant positive impact on the number of women in the online shop and the number of female management.

3.3 In Taobao Village, the employment opportunities created by the development of e-commerce have the characteristics of diversity, flexibility and proximity. Common e-commerce has both directly related positions, such as shop customer service, marketing specialist, packing and shipping specialist, but also e-commerce driven positions, such as the tailor garment industry, furniture industry carpentry, couriers, photographers and so on. In recent years, part of Taobao Village also emerged as a network service provider lawyers, accounting, patent agents. This section uses the number of online stores as a measure of employment to verify the relationship between inclusive innovation performance and employment resolution.

H3: Inclusive innovation performance and employment have a significant positive impact, which is the higher the degree of inclusive innovation, the more employment settlement.

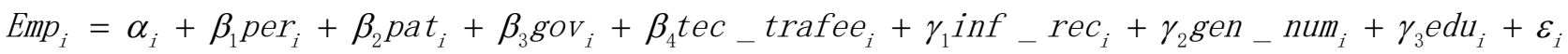


Table 3 Regression analysis results

\begin{tabular}{|c|c|c|c|c|c|c|}
\hline variable & (1) & (2) & (3) & (4) & (5) & (6) \\
\hline Per & $\begin{array}{c}0.946 * * * \\
(0.240)\end{array}$ & & & & $\begin{array}{c}0.844 * * * \\
(0.238) \\
\end{array}$ & $\begin{array}{l}0.804^{* * *} \\
(0.764) \\
\end{array}$ \\
\hline Pat & & $\begin{array}{c}0.333 * * * \\
(0.327) \\
\end{array}$ & & & $\begin{array}{c}0.202 * * * \\
(0.331) \\
\end{array}$ & $\begin{array}{l}0.937 \\
(0.151) \\
\end{array}$ \\
\hline Gov & & & $\begin{array}{c}-0.732 \\
(0.557) \\
\end{array}$ & & $\begin{array}{l}-0.375 \\
(0.543) \\
\end{array}$ & $\begin{array}{c}-0.197 * * * \\
(0.549)\end{array}$ \\
\hline tec_trafee & & & & $\begin{array}{c}0.083 \\
(0.226) \\
\end{array}$ & $\begin{array}{l}0.243 \\
(0.220)\end{array}$ & $\begin{array}{c}0.892^{*} \\
(0.828)\end{array}$ \\
\hline inf_rec & $\begin{array}{l}0.095 * \\
(0.483) \\
\end{array}$ & $\begin{array}{l}0.402 * \\
(0.488)\end{array}$ & $\begin{array}{c}0.193 \\
(0.542) \\
\end{array}$ & $\begin{array}{c}0.687 \\
(0.519) \\
\end{array}$ & $\begin{array}{l}0.707^{*} \\
(0.523)\end{array}$ & \\
\hline gen_num & $\begin{array}{l}0.880 * * * \\
(0.066)\end{array}$ & $\begin{array}{c}0.972 * * * \\
(0.057)\end{array}$ & $\begin{array}{c}0.006 * * * \\
(0.058)\end{array}$ & $\begin{array}{l}0.015 * * * \\
(2.015)\end{array}$ & $\begin{array}{c}0.815^{* * *} \\
(0.071)\end{array}$ & \\
\hline$E d u$ & $\begin{array}{l}-0.225 \\
(0.164)\end{array}$ & $\begin{array}{l}-0.275 \\
(0.164)\end{array}$ & $\begin{array}{l}-0.195 \\
(0.170)\end{array}$ & $\begin{array}{c}-0.241 \\
(-0.241)\end{array}$ & $\begin{array}{l}-0.264 \\
(0.166)\end{array}$ & \\
\hline $\mathrm{R} 2$ & 0.794 & 0.795 & 0.786 & 0.785 & 0.803 & 0.129 \\
\hline $\mathrm{N}$ & 359 & 359 & 359 & 359 & 359 & 503 \\
\hline
\end{tabular}

Theorem3. E-business performance and design patent number have a significant positive impact on employment. The effect of annual government subsidy and technology training on employment remains significant.

3.4 This section uses subjective learning ability, subjective gender equality, and subjective subordination of the father as the measure of ideological concepts to test the impact of inclusive innovation performance on ideological concepts.

H4: Inclusive innovation has a significant positive effect on the change of ideology, that is, the higher the degree of inclusiveness, the greater the change of ideology and concept.

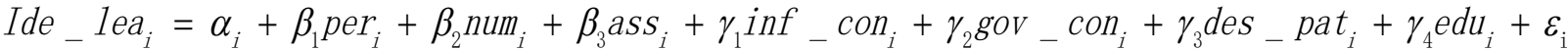

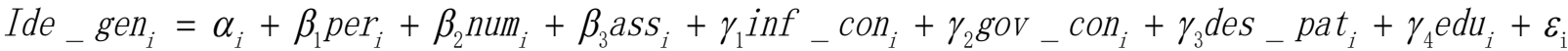

$$
\begin{aligned}
& \text { Ide_inh } h_{i}=\alpha_{i}+\beta_{1} \text { per }_{i}+\beta_{2} \text { num }_{i}+\beta_{3} a S S_{i}+\gamma_{1} i n f_{-} c o n_{i}+\gamma_{2} \text { goV }_{-} \text {con }_{i}+\gamma_{3} d e S_{-} p a t_{i}+\gamma_{4} e d u_{i}+\varepsilon_{\mathrm{i}}
\end{aligned}
$$

Table 4 Regression analysis results

\begin{tabular}{c|c|c|c|c|c|c}
\hline \multirow{2}{*}{ variable } & \multicolumn{2}{|c|}{ Basic estimation } & \multicolumn{2}{c|}{ Robustness test } & \multicolumn{2}{c}{ Robustness test } \\
\cline { 2 - 7 } & \multicolumn{2}{|c|}{ Ide_lea } & \multicolumn{2}{c}{ Ide_gen } & \multicolumn{2}{c}{ Ide_inh } \\
\cline { 2 - 7 } & $(1)$ & $(2)$ & $(3)$ & $(4)$ & $(5)$ & $(6)$ \\
\hline \multirow{2}{*}{ per } & $0.081^{* * *}$ & $0.095^{* *}$ & $0.140^{* * *}$ & $0.167^{* * *}$ & $0.020^{*}$ & $0.033^{* * *}$ \\
& $(0.018)$ & $(0.017)$ & $(0.023)$ & $(0.023)$ & $(0.009)$ & $(0.009)$ \\
\hline \multirow{2}{*}{ num } & $0.004^{* * *}$ & $0.005^{* * *}$ & $0.004^{* *}$ & $0.005^{* * *}$ & 0.001 & 0.020 \\
& $(0.001)$ & $(0.022)$ & $(0.003)$ & $(0.021)$ & $(0.010)$ & $(0.001)$ \\
\hline \multirow{2}{*}{ ass } & $-0.230^{*}$ & -0.185 & $0.816^{* * *}$ & $0.879^{* * *}$ & $0.174^{*}$ & $0.152^{* *}$ \\
& $(0.102)$ & $(0.099)$ & $(0.133)$ & $(0.131)$ & $(0.052)$ & $(0.052)$ \\
\hline \multirow{2}{*}{ inf_con } & 0.202 & & -0.146 & & $0.221^{*}$ & \\
& $(0.216)$ & & $(0.282)$ & & $(0.110)$ & \\
\hline \multirow{2}{*}{ gov_con } & $0.006^{*}$ & & 0.004 & & 0.000 & \\
& $(0.002)$ & & $(0.003)$ & & $0.001)$ & \\
\hline \multirow{2}{*}{ des_pat } & 0.025 & & 0.027 & & $-0.037^{*}$ & \\
& $(0.026)$ & & $(0.034)$ & & $0.013)$ & \\
\hline \multirow{2}{*}{ edu } & -0.018 & & $-0.073^{* * *}$ & & $0.035^{* * *}$ & \\
& $(0.014)$ & & $(0.018)$ & & $(0.007)$ & \\
\hline R2 & 0.137 & 0.094 & 0.223 & 0.152 & 0.157 & 0.064 \\
\hline $\mathrm{N}$ & 491 & 503 & 491 & 503 & 491 & 503 \\
\hline
\end{tabular}

Theorem4. E-business performance has a significant positive impact on ideological concepts, 
subjective equality between men and women, and subjective subordination of father to father; the scale of online shop (the current number of online shop) has a significant positive effect on subjective learning ability and subjective equality between men and women. Subjective sub-bearing father influence is not significant. The participation of E-commerce associations in online retailers has a negative impact on subjective learning ability, but not significant. while it has a significant positive impact on subjective equality of men and women and subjectivity.

\section{Conclusion}

The research on innovation system is mostly macro-level of national innovation system and regional inclusive innovation system. However, the research on inclusive innovation system based on Taobao village is rarely involved, and the concept of inclusive innovation system at the micro level is lacking Defined. (1) This study pioneered the evaluation index system of inclusive innovation system from the microscopic perspective. (2) The use of research to obtain micro-data, to avoid the statistical department's macro data defects. (3) Using quantitative research methods to make up for the lack of qualitative research of inclusive innovation. (4) In this study, inclusive innovation performance as an explanatory variable, the value of inclusive innovation system evaluation.

In the past, the research on inclusive innovation started with income rather than economic poverty. Drawing on the UN Millennium Development Goals and the 2010 Human Development Report, this study considered the solution of inclusive innovation in addition to economic poverty Employment, eliminating gender inequalities and changing the mindset. From the perspective of technical operation, previous researches all took inclusive innovation performance as explanatory variables, and only examined which factors affected the improvement of inclusive innovation performance. In this study, inclusive innovation performance was taken as explanatory variables, and income change indicators, employment indicators, Indicators of gender inequality and ideological concepts as explanatory variables to verify the impact of inclusive innovation on the above factors to evaluate the economic and social value of inclusive innovation.

\section{Reference}

[1] Hanna Nari Kahle,Anna Dubiel,Holger Ernst,Jaideep Prabhu. The democratizing effects of frugal innovation: Implications for inclusive growth and state-building[J]. Journal of Indian Business Research,2013,54:.

[2] Zhihong ZENG,Zhizhang WANG,Xiaoying ZENG. The Poverty Alleviation Model of Local Government Inclusive Innovation: A Case Study on Contiguous Poor Regions in China[J]. Cross-Cultural Communication,2013,94:.

[3] Zhizhang WANG,Mengzhu LI,Cuicui HE. Inclusive Innovation Path Design of the New-Type Urbanization Development in Multiple-Block-Joint Impoverished Regions[J]. Studies in Sociology of Science,2014,51:

[4] Zhihong ZENG,Abulrahman Suleiman Abulrahman Suleiman Abdulrahman,Xiaoying Zeng. Research on Inclusive Innovation Mode of Sustainable Development in Three Gorges Reservoir Area[J]. Management Science and Engineering,2014,82:.

[5] Sui TAN. Study on the Inclusive System Innovation of China's New Urbanization[J]. Cross-Cultural Communication,2015,1111:. 